\title{
Characteristics of the physical and chemical parameters of water in pools of port in Szczecin in 2009
}

\author{
Emil Cyraniak ${ }^{1}$, Piotr Daniszewski ${ }^{2, *}$, Beata Draszawka - Bołzan ${ }^{3}$ \\ ${ }^{1}$ The Board of Marine Ports of Szczecin and Świnoujście S.A., \\ Environment and Health Research Laboratory, 7 Bytomska Street, 70-603 Szczecin, Poland \\ ${ }^{2}$ Department of Invertebrate Zoology and Limnology, University of Szczecin, \\ 13 Wąska Street, 71-415 Szczecin, Poland \\ ${ }^{3}$ Department of Chemistry and Protection of the Aquatic Environment, University of Szczecin, \\ 3C Felczaka Street, 71-412 Szczecin, Poland \\ *E-mail address: daniszewski@univ.szczecin.pl
}

\begin{abstract}
The aim of this work was to be traced during the summer and autumn of 2009 the level and dynamics of changes in the waters of the Port of Szczecin General docks parameters water quality. In the work of the General indicators of water temperature, were numbered: $\mathrm{pH}, \mathrm{BOD}_{5}, \mathrm{COD}-\mathrm{Cr}, \mathrm{Cl}^{-}$. All the markings and the calculation was performed according to the methods recommended by Polish Standards, applying analytical procedures described in by Dojlido, Elbanowska, Hermanowicz. Port of Szczecin is located on the Oder river and its right shoulder Regalicy. Is located in the western part of the port of Szczecin, in the northern part of the Valley of the lower Oder river on May. The port consists of water bodies which are branches of the Oder river and the channels: Mieleński, Grabowski, Dunczyca Channel Figh, Wroclaw, Parnica, Channel Channel Debicki and Lake Dabie. Trying is water were collected by PN/C-04632.03 with a depth of about. $2 \mathrm{~m}$ below the water surface. The temperature at the place of sampling were numbered, $\mathrm{pH}$. Collected water samples were fixed in accordance with the recommendations in the Polish Standard-PN/C-04632.04. Other indicators for the quality of the waters have been tagged within 24 hours from the moment of download attempts. The quality objectives was evaluated according to the criteria recommended to evaluate inland surface waters referred to in regulation of the Minister of the environment of 11 February 2004 on the classification for the present status of surface water and groundwater, how to conduct monitoring and how to interpret the results and presentation of these waters. Due to the exposure of the docks the port Szczecin on the pollution associated with cross-what are the cereals, ores, oil, cellulose, carbon, iron, general research evaluation of the water quality of these pools, you can assess the status of water in order to keep these waters.
\end{abstract}

Keywords: swimming pools port; natural water quality; $\mathrm{pH}, \mathrm{BOD}_{5} ; \mathrm{COD}-\mathrm{Cr} ; \mathrm{Cl}^{-}$ 


\section{INTRODUCTION}

The main roles in the natural environment are the reservoirs are: hydrological, micro climatical, hydro sanitary role, industrial $[1,2,5,7-10,12,14,16,18,19]$.

In accordance with the Water Framework Directive, by 2015 all water, including the waters of the port facilities, should have a good ecological status [1, 3, 6-9, 12, 15, 16, 19-21].

Docks are among the areas, which are particularly vulnerable to water pollution in connection with cross-what may place on their site $[4-6,8,9,11,13,16,17,20,21,24-29,32$, 33]. The primary function of the port of Szczecin is the import of grain, ores, oil, paper, cellulose, granite blocks, general cargo and export of coal, iron, grain, general cargo [5, 6, 16, 17, 31, 33-40]. Docks in Szczecin are located in the estuary of the Oder river. The estuary of the Oder river is characterized by considerable volatility also affects the hydrological conditions, what the status of the water quality of swimming pools located in the city of Szczecin port $[5,6,16,17,38-40]$.

During the summer and autumn of 2009, a study of water quality of the port in Port Szczecin-Mining, 10 pools, Kashubian, worth, Notecki, Mielenski, Parnica, East, West, Kanal Debicki, Workbench. In the downloaded samples of water were numbered 4 water quality indicators, which characterize the State of water quality.

\section{PART OF THE EXPERIMENTAL}

Tests have been carried out on the docks in the port of Szczecin 10 years and fall 2009. Port of Szczecin is situated in the western part of the province. the West, in the central part of Szczecin, in Downtown [5, 6, 16, 17, 33, 39, 40]. Is ok. $69 \mathrm{~km}$ South from the Bay of Pomerania and ok. $11 \mathrm{~km}$ from the Lagoon of Szczecin [5, 6, 16, 17, 33, 39, 40]. On a map No 1 and 2 shows the location of the port of Szczecin.

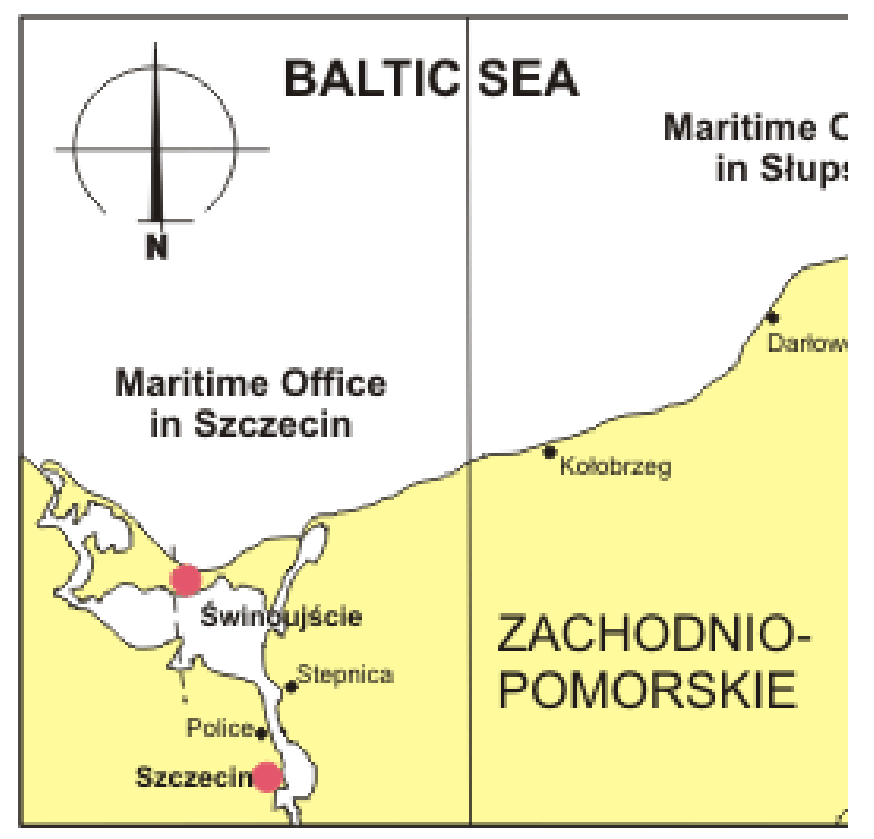

Map 1. Location of the port of Szczecin. Source: The Sea in Szczecin 


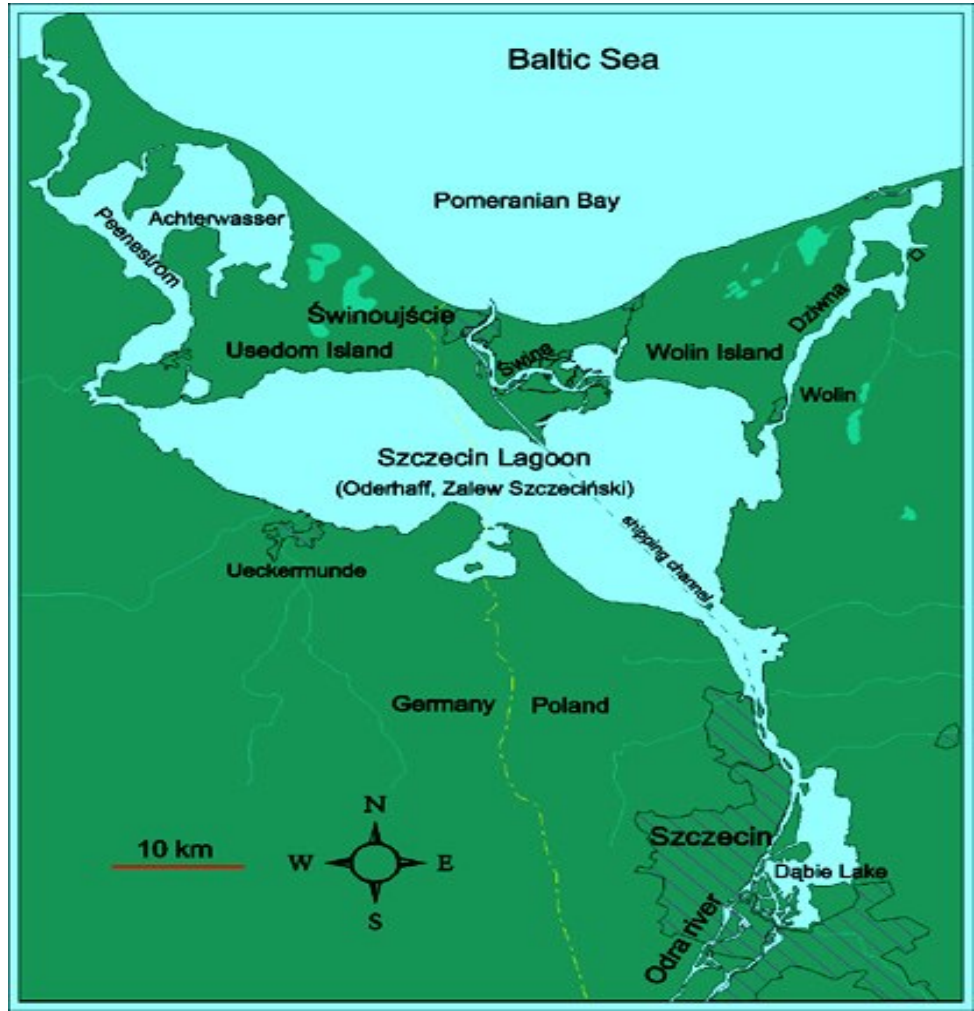

Map 2. Location of the port of Szczecin. Source: The Sea in Szczecin

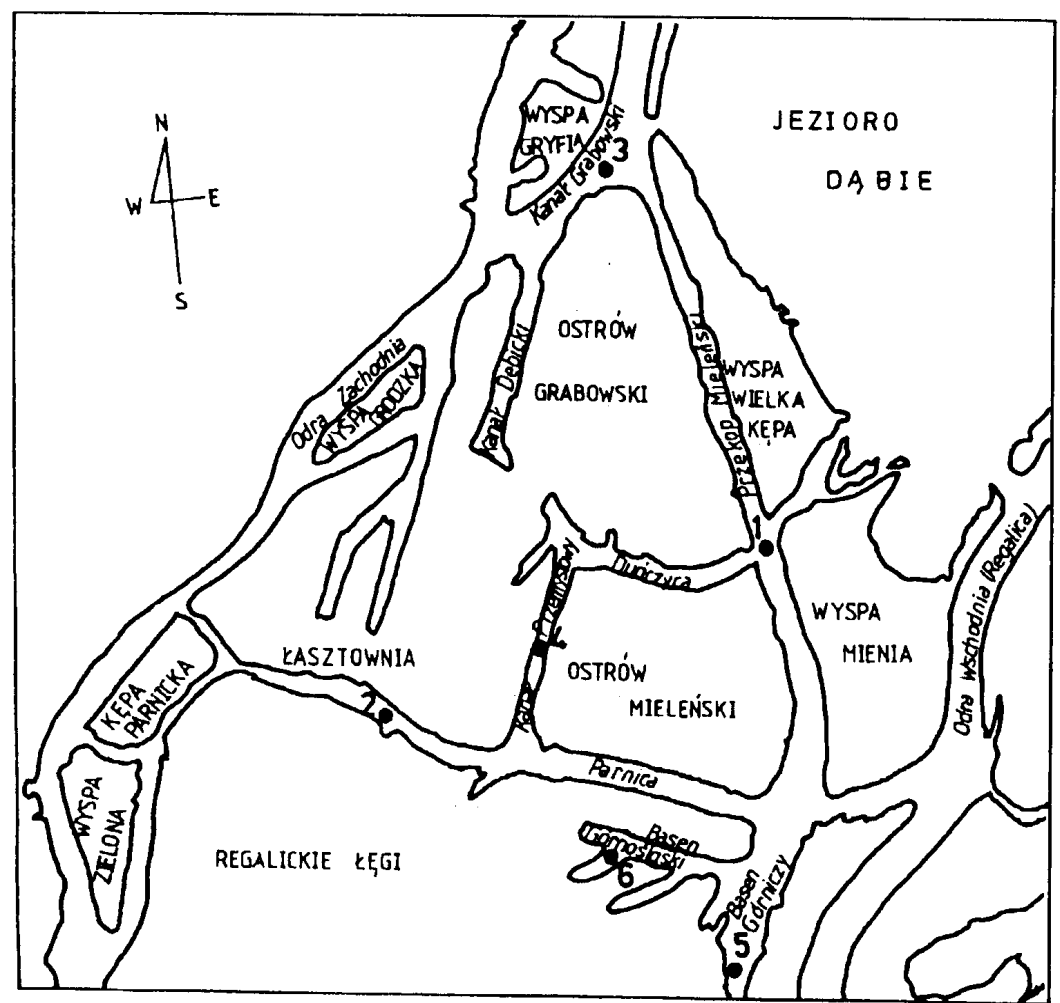

Fig. 1. Map channels and pools Port in Szczecin. Source: Board of Szczecin-Świnoujście Ports 
Port of Szczecin is located on the Oder river and its right shoulder Regalicy. Is located in the western part of the port of Szczecin, in the northern part of the Valley of the lower Oder river on May [5, 6, 16, 17, 33, 39, 40]. The port consists of water bodies which are branches of the Oder river and the channels: Mieleński, Grabowski, Duńczyca Channel Figh, Wroclaw, Parnica, Channel Dębicki and Lake Dąbie [5, 6, 16, 17, 33, 39, 40]. In Figure 1 was presented the map channels and pools Port in Szczecin.

Port of Szczecin has 103 named the waterfront, these are: Huty, Cementowe, Fosforowe, Południowe, Fosforowe Dalby, Snop, Bunkrowe, Huk, Żeglugowy Basen, Hydrograficzne, BTP, BON, Mak, Jachtowy Basen, Golecińskie, Oko, Oko Basen, Cal, Drab II, Młyński Basen, Drab III, Warsztatowy Basen, Warsztatowe, Promowy Basen, Wulkan, Drzetowskie Północne, Drzetowskie Południowe, Odra Stare, Odra Nowe, Wrocławskie, Warszawskie, Radomskie, Kieleckie, Gdyńskie, Gdańskie, Przydekowe, Kaszubskie, Lańcuchowe, Mazowieckie, Wyposażeniowe, Gnieźnieńskie, Krakowskie, Arsenal, Kapitanatu, Pasażerskie, Bulwar Chrobrego, Wieleckie, Starówka, Bułgarskie, Tureckie, Rosyjskie, Kubańskie, Jugosłowiańskie, Albańskie, Greckie, Egipskie, Rumuńskie, Węgierskie, Polskie, Angielskie, Belgijskie, Holenderskie, Luksemburskie, Zbożowe, Niemieckie, Słowackie, Czeskie, Spółdzielcze, Fińskie, Ciche, PRCiP, Przemysłowe, Farblak, Remontowe, PRO, Nowe, Elektrowni, CPN-3, Parnickie, Naftowe, CPN-1, Sosnowieckie, Kokschemii, Opolskie, Dolnośląskie, Noteckie, Gorzowskie, Drawskie, Górnośląskie, Poznańskie, Toruńskie, Bydgoskie, Rybnickie, Wałbrzyskie, Czołowe, Pirs, Bytomskie, Południowe, Gliwickie, Chorzowskie, Katowickie, Zabrzańskie, Dąbrowieckie [33, 39, 40].

Trying to test water were collected by PN/C-04632.03 with a depth of about. $2 \mathrm{~m}$ below the water surface. The temperature at the place of sampling were numbered, $\mathrm{pH}$.

Collected water samples were fixed in accordance with the recommendations in the Polish Standard - PN/C-04632.04.

Other indicators for the quality of the waters have been tagged within 24 hours from the moment of download attempts.

In this work of physico-chemical indicators assessed waters marked concentration: $\mathrm{BOD}_{5}$ in accordance with PN-EN 1899-2:2002, COD in accordance with PN-ISO 15705:2005, chloride in accordance with PN-ISO 9297:1994.

The individual indicators of water quality was evaluated according to the criteria recommended to evaluate inland surface waters referred to in regulation of the Minister of the environment of 11 February 2004 on the classification for the present status of surface water and groundwater, how to conduct monitoring and how to interpret the results and presentation of these waters.

\section{DISCUSSION OF THE RESULTS}

The results of the quality of surface water docks the port Szczecin during the summer and autumn of 2009 together with the test value indicators according to the classification criteria of the regulation of the Minister of the environment of 11 February 2004, are presented in tables 1 and 2. 
Table 1. The results of the quality of surface water docks the port Szczecin together with the test value indicators according to the classification criteria of the regulation of the Minister of the environment of 11 February 2004, during the summer of 2009

\begin{tabular}{|c|c|c|c|c|}
\hline \multirow{2}{*}{ The test pool } & \multicolumn{4}{|c|}{ Water quality indices (units) } \\
\cline { 2 - 5 } & $\mathrm{pH}$ & $\begin{array}{c}\mathrm{BOD} \\
\left(\mathrm{BgO}_{2} \cdot \mathrm{dm}^{-3}\right)\end{array}$ & $\begin{array}{c}\mathrm{COD}-\mathrm{Cr} \\
\left(\mathrm{mgO}_{2} \mathrm{dm}^{-3}\right)\end{array}$ & $\begin{array}{c}\mathrm{Cl}^{-} \\
\left(\mathrm{mg} \mathrm{Cl}^{-} \mathrm{dm}^{-3}\right)\end{array}$ \\
\hline Górniczy & $8,47(\mathrm{I})$ & $5,00(\mathrm{III})$ & $21,60(\mathrm{III})$ & $117,20(\mathrm{I})$ \\
\hline Kaszubski & $8,25(\mathrm{I})$ & $4,40(\mathrm{III})$ & $28,37(\mathrm{III})$ & $116,10(\mathrm{I})$ \\
\hline Warty & $7,82(\mathrm{I})$ & $1,63(\mathrm{I})$ & $17,00(\mathrm{II})$ & $114,00(\mathrm{I})$ \\
\hline Notecki & $7,84(\mathrm{I})$ & $2,03(\mathrm{II})$ & $16,50(\mathrm{II})$ & $114,40(\mathrm{I})$ \\
\hline Mieleński & $7,95(\mathrm{I})$ & $3,21(\mathrm{III})$ & $19,50(\mathrm{II})$ & $125,00(\mathrm{I})$ \\
\hline Parnica & $8,02(\mathrm{I})$ & $3,66(\mathrm{III})$ & $21,20(\mathrm{III})$ & $132,60(\mathrm{I})$ \\
\hline Wschodni & $8,14(\mathrm{I})$ & $6,66(\mathrm{IV})$ & $22,60(\mathrm{III})$ & $116,00(\mathrm{I})$ \\
\hline Zachodni & $7,97(\mathrm{I})$ & $5,80(\mathrm{III})$ & $22,40(\mathrm{III})$ & $122,00(\mathrm{I})$ \\
\hline Kanal Dębicki & $7,91(\mathrm{I})$ & $4,36(\mathrm{III})$ & $18,40(\mathrm{II})$ & $124,90(\mathrm{I})$ \\
\hline Warsztatowy & $7,33(\mathrm{I})$ & $6,00(\mathrm{III})$ & $25,30(\mathrm{III})$ & $137,40(\mathrm{I})$ \\
\hline
\end{tabular}

Explanation: I, II, III, IV-classification values of the indicator according to the criteria of the regulation of the Minister of the environment of 11 February 2004.

Table 2. The results of the quality of surface water docks the port Szczecin together with the test value indicators according to the classification criteria of the regulation of the Minister of the environment of 11 February 2004, during the autumn of 2009

\begin{tabular}{|c|c|c|c|c|}
\hline \multirow{2}{*}{ The test pool } & \multicolumn{4}{|c|}{ Water quality indices (units) } \\
\cline { 2 - 5 } & $\mathrm{pH}$ & $\begin{array}{c}\mathrm{BOD} \mathrm{BO}_{5} \\
\left(\mathrm{mgO}_{2} \cdot \mathrm{dm}^{-3}\right)\end{array}$ & $\begin{array}{c}\mathrm{COD}-\mathrm{Cr} \\
\left(\mathrm{mgO}_{2} \cdot \mathrm{dm}^{-3}\right)\end{array}$ & $\begin{array}{c}\mathrm{Cl}^{-} \\
\left(\mathrm{mg} \mathrm{Cl}^{-} \cdot \mathrm{dm}^{-3}\right)\end{array}$ \\
\hline Górniczy & $7,82(\mathrm{I})$ & $2,10(\mathrm{II})$ & $15,70(\mathrm{II})$ & $161,10(\mathrm{I})$ \\
\hline Kaszubski & $7,84(\mathrm{I})$ & $1,71(\mathrm{I})$ & $15,80(\mathrm{II})$ & $149,10(\mathrm{I})$ \\
\hline Warty & $7,89(\mathrm{I})$ & $1,88(\mathrm{I})$ & $15,20(\mathrm{II})$ & $146,30(\mathrm{I})$ \\
\hline Notecki & $7,76(\mathrm{I})$ & $1,40(\mathrm{I})$ & $14,60(\mathrm{II})$ & $155,60(\mathrm{I})$ \\
\hline Mieleński & $7,91(\mathrm{I})$ & $1,88(\mathrm{I})$ & $17,80(\mathrm{II})$ & $119,50(\mathrm{I})$ \\
\hline Parnica & $7,89(\mathrm{I})$ & $2,01(\mathrm{II})$ & $17,20(\mathrm{II})$ & $126,40(\mathrm{I})$ \\
\hline Wschodni & $7,84(\mathrm{I})$ & $1,41(\mathrm{I})$ & $15,50(\mathrm{II})$ & $138,20(\mathrm{I})$ \\
\hline Kachodni & $7,87(\mathrm{I})$ & $1,80(\mathrm{I})$ & $14,50(\mathrm{II})$ & $126,60(\mathrm{I})$ \\
\hline Warsztatowy & $7,61(\mathrm{I})$ & $1,95(\mathrm{I})$ & $16,70(\mathrm{II})$ & $124,10(\mathrm{I})$ \\
\hline
\end{tabular}

Explanation: I, II-classification values of the indicator according to the criteria of the regulation of the Minister of the environment of 11 February 2004. 
Water pools in the port of Szczecin port of research have a $\mathrm{pH}$ value close to neutral or slightly alkaline-research have been included throughout the period and water quality class according to the criteria of the regulation of the Minister of the environment of 11 February 2004.

Aquatic ecosystems studied pools tested the value of $\mathrm{BOD}_{5}$ developed mainly for water level and quality in the autumn and II class of 2009, while the value of this indicator during the years she was at level III and IV water quality class according to the criteria of the regulation of the Minister of the environment of 11 February 2004.

The level of COD in research developed at the level of the period II and III class water quality. Throughout the period of the test water docks Harbour water quality assessment indicators from Szczecin have and class to class IV.

\section{CONCLUSIONS}

Due to the exposure of the docks the port Szczecin on the pollution associated with cross-what are the cereals, ores, oil, cellulose, carbon, iron, general research evaluation of the water quality of these pools, you can assess the status of water in order to keep these waters.

\section{POLISH STANDARD}

PN/C-04632.03. General rules for sampling for the study of the physical, chemical and biological. Sampling technique.

PN/C-04632.04. General rules for sampling for the study of the physical, chemical and biological. Recording and storage of samples.

PN/C-06504. The preparation of buffer solutions.

PN-90/C-04540/01 - determination of $\mathrm{pH}$.

PN-EN 1899-2:2002 - determination of $\mathrm{BOD}_{5}$.

PN-ISO 15705:2005 - determination of COD.

PN-ISO 9297:1994 - determination of chlorides.

\section{REFERENCES}

[1] Barik S. K., Purushothaman C. S., Mohanty A. N., Aquacult. Res. 32 (2001) 819-832.

[2] Bowden K. F., Oceanic and Estuarine Mixing Processes. W: Riley J. P., Skirrow G., (eds.), Chemical Oceanography. London-New York-San Francisco, 1974, 1-41

[3] Buchholz W., Materiaty Sesji Naukowej KBM PAN. Szczecin (1990), 49-70

[4] Buchholz W., Warunki hydrologiczno-hydrodynamiczne, Prace IBW PAN, Gdańsk 22 (1990) 1-117

[5] Cyraniak E., Daniszewski P., Draszawka - Bołzan B., International Letters of Chemistry, Physics and Astronomy 5 (2012) 88-95. 
[6] Cyraniak E., Daniszewski P., Draszawka - Bołzan B., International Letters of Chemistry, Physics and Astronomy 5 (2012) 96-103

[7] Daniszewski P. Ekologia i Technika 5 (2008) 211-214

[8] Daniszewski P., Wiadomości Melioracyjne i Łąarskie 4 (2008) 187-188

[9] Daniszewski P., Inżynier budownictwa 11 (2009) 81-82

[10] Daniszewski P., Gaz, Woda i Technika Sanitarna 4 (2009) 34-36.

[11] Daniszewski P., International Letters of Chemistry, Physics and Astronomy 1 (2012) 6-12.

[12] Daniszewski P., International Letters of Chemistry, Physics and Astronomy 1 (2012) 13-16.

[13] Daniszewski P., International Letters of Chemistry, Physics and Astronomy 2 (2012) $42-45$

[14] Daniszewski P., International Letters of Chemistry, Physics and Astronomy 2 (2012) 46-52

[15] Daniszewski P., International Letters of Chemistry, Physics and Astronomy 2 (2012) $35-41$

[16] Daniszewski P., Draszawka - Bołzan B., International Letters of Chemistry, Physics and Astronomy 4 (2012) 96-102.

[17] Daniszewski P., Draszawka - Bołzan B., International Letters of Chemistry, Physics and Astronomy 4 (2012) 103-111.

[18] Daniszewski P., International Letters of Chemistry, Physics and Astronomy 4 (2012) 112-118.

[19] Daniszewski P., International Letters of Chemistry, Physics and Astronomy 4 (2012) 119-124.

[20] Daniszewski P., International Letters of Chemistry, Physics and Astronomy 5 (2012) $72-79$

[21] Daniszewski P., International Letters of Chemistry, Physics and Astronomy 5 (2012) 80-87

[22] Demel K., Życie morza, Gdańsk, 1974.

[23] Dojlido J. R., Chemia wód powierzchniowych. Wydawnictwo Ekonomia i Środowisko 1995

[24] Druet C., Elementy hydrodynamiki geograficznej, Warszawa 1995.

[25] Elbanowska H., Zerbe J., Siepak J., Fizyczno-chemiczne badania wód, Wydawnictwo Naukowe PWN 1999, ss. 232

[26] Grasshoff K., Methods of Seawater Analysis, Weinheim-New York, 1976.

[27] Hermanowicz W., Dojlido J., Dożańska W., Koziorowski B., Zerbe J., Fizyczno-chemiczne badanie wody i ścieków, Arkady, Warszawa 1999.

[28] Jasińska E. Inst. Budownictwa Wodnego PAN (1991), 24, 1-206

[29] Kajak Z., Ekosystemy wód śródlądowych, PWN, Warszawa (1998), s. 355. 
[30] Ryszard Kotla R., Magazyn Portowy 1 (2007) 32

[31] Leybovich S., Ulrich D., J. Geophys. Res. 77 (1972) 1683-1688

[32] Lyman J., Chemical consideration, physical and chemical properties of sea water. Washington, cited after: Monin A. S., (red.), 1979, Chimija okieana. T. 1, Chimija wod okieana. Moskwa 1959.

[33] Majewski A., (red.), Zalew Szczeciński, Warszawa 1980.

[34] Majewski A., Prace PIHM, 105 (1972) 3-37

[35] Majewski A., Charakterystyka hydrologiczna Zatoki Pomorskiej. Warszawa 1974.

[36] Mikulski Z., Biul. PIHM, 5 (1960) 1-23

[37] Młodzińska Z., Zawartość tlenu, W: Majewski A. (red.), Zalew Szczeciński. Warszawa, (1980) 223-230

[38] Młodzińska Z., Hydrochemia. W: Majewski A. (red.), Zalew Szczeciński. Warszawa, (1980) 248-277

[39] Port Szczecin. Informacja ogólne, Urząd Morski w Szczecinie. 2009

[40] Port w Szczecinie nabrzeża, Zarząd Morskich Portów Szczecin i Świnoujście SA. 2009 